\title{
Pengembangan Paralayang Ternadi di Kabupaten Kudus
}

\author{
Nanang Indardi, Sahri Sahri \\ Jurusan Ilmu Keolahragaan, Fakultas Ilmu Keolahragaan, \\ Universitas Negeri Semarang, Indonesia
}

Diterima: 16 Oktober 2019. Direvisi: 03 Juni 2020. Disetujui: 03 Juli 2020

\begin{abstract}
Abstrak: Paralayang sejak tahun 1990an sudah berkembang di Jawa Tengah, namun sampai sekarang perkembangannya masih kalah dengan daerah Jawa Timur dan Jawa Barat. Penelitian dilakukan untuk mengkaji pengembangan Paralayang Ternadi sebagai ikon pariwisata udara oleh Pengurus Provinsi Paralayang Jawa Tengah. Penelitian ini bertujuan untuk memudahkan pemetaan pengembangan tempat paralayang sesuai dengan karakteristik alam setempat dan secara umum aktivitas wisata paralayang dapat berkembang dan menjadi lebih baik sesuai standar operasi prosedur serta keamanan penerbangan. Pengkajian potensi pengembangan paralayang ini diharapkan mampu meningkatkan pengetahuan, kemampuan terbang, dan airmanship/tingkah laku, serta menjadi daya tarik wisata udara dalam dunia penerbangan paralayang. Tertatanya potensi pengembangan paralayang dan tata kelola paralayang yang lebih terorganisir dengan baik merupakan dampak positif yang ingin dicapai. Penelitian ini bersifat eksploratif dan dilakukan di Kabupaten Kudus. Penelitian ini dilaksanakan dalam tiga tahap dengan meliputi pengamatan lapangan, pemetaan, dan tata kelola. Pengamatan lapangan dilakukan dengan menggunakan pengamatan langsung dengan menggunakan media (gambar, rekaman audio/visual) serta didampingi pakar dan melibatkan lembaga yang berkompeten. Pemetaan tempat dilakukan dengan memperhatikan potensi alam yang mendukung (ketinggian, arah angin, kontur tanah, luasan lahan, sumber air, dan lain-lain). Tata kelola diperlukan untuk memastikan kelangsungan pengembangan paralayang secara menyeluruh dalam kurun waktu yang relatif lama.
\end{abstract}

Kata kunci: paralayang, pariwisata, ternadi

Abstract: Paragliding since the 1990s has been developing in Central Java, but until now its development is still inferior to the regions of East Java and West Java. The study was conducted to examine the development of Ternadi Paragliding as an icon of air tourism by the Central Java Paragliding Management. This study aims to facilitate the mapping of the development of paragliding sites in accordance with local natural characteristics and in general paragliding tourism activities can develop and become better according to standard operating procedures and flight safety. The assessment of the potential of paragliding development is expected to be able to improve knowledge, flight ability, and airmanship / behavior, as well as being an attraction for air travel in the world of paragliding flights. The organized potential of the development of paragliding governance that is better organized is a positive impact to be achieved. This research is exploratory and conducted in Kudus Regency. This research was carried out in three phases which included field observations, mapping and governance. Field observations are carried out using direct observations using media (images, audio/visual recordings) and accompanied by experts and involving competent institutions. Site mapping is done by taking into account the supporting natural potential (altitude, wind direction, land contour, land area, water source, etc.). Governance is needed to ensure the continued development of paragliding as a whole in a relatively long period of time.

Keywords: paragliding, tourism, ternadi

\section{PENDAHULUAN}

Indonesia memiliki banyak pegunungan yang tersebar dari Sabang sampai Merauke, dan dibandingkan daerah lain Jawa memiliki deretan pegunungan paling banyak. Jawa Tengah paling banyak memiliki pegunungan sebanyak 10 gunung, yang merupakan sumber daya alam potensial untuk pengembangan olahraga paralayang. Tahun 1990an perkembangan paralayang di Jawa Tengah relatif kurang pesat, hal ini dipengaruhi oleh tidak adanya pengembangan yang sinergi dan program pembinaan berkelanjutan dari berbagai pihak yang kompeten. Program pembinaan dan pengembangan olahraga paralayang di Jawa Tengah hanya difokuskan pada peningkatan prestasi (atlet), sehingga bidang garapan lainnya (olahraga pendidikan dan olahraga rekreasi) kurang mendapat perhatian (UU SKN no. 3: 2005). Hal ini bertentangan dengan bunyi peraturan Undang-Undang Sistem Keolahragaan Nasional nomor 3 tahun 2005, pasal 1 ayat 1 yang menyatakan bahwa keolahragaan adalah segala aspek yang berkaitan dengan olahraga yang memerlukan pengaturan, pendidikan, pelatihan, pembinaan, pengembangan, dan pengawasan. Untuk mewujudkan cita-cita tersebut maka FASI (Federasi Aero Sport Indonesia) berkewajiban untuk membentuk Pordirga Paralayang yang merupakan persatuan olahraga dirgantara aneka cabang 
yang memiliki lokasi dirgantara dan memenuhi syarat kelaikan dalam pengembangan dan pembinaan olahraga dirgantara, khususnya pengembangan paralayang.

Olahraga paralayang bisa berkembang dengan baik jika mendapat dukungan berupa sumber daya alam, sumber daya manusia, infrastruktur, serta organisasi yang sehat. Di Jawa Tengah sumber daya alam cukup banyak yang tersebar, salah satunya berada di kaki gunung Muria yang bernama Bukit Ternadi sebagai tempat sentralisasi Kabupaten $\mathrm{Ku}$ dus, karena daerah tersebut juga sudah mempunyai organisasi legal FASI bidang paralayang, dan banyak perusahaan besar yang siap membackup olahraga pendidikan paralayang. Untuk mewujudkan hal diatas metode pengembangan Paralayang/Paragliding Ternadi sangat sesuai dengan geografis Kabupaten $\mathrm{Ku}$ dus. Paragliding Ternadi memiliki tujuan untuk membina, mengembangkan, dan menciptakan pendidikan yang terarah dan sistematis untuk mendukung regenerasi pilot paralayang sesuai AD/ART FASI tahun 2010.

Paralayang merupakan olahraga terbang bebas dengan menggunakan sayap kain (parasut) yang lepas landas dari lereng bukit dengan kaki untuk tujuan rekreasi atau kompetisi. Induk organisasi paralayang adalah PGPI (Persatuan Olahraga Dirgantara Gantole dan Paralayang Indonesia) dibawah naungan FASI. Paralayang lepas landas dari lereng dengan memanfaatkan angin sebagai sumber daya angkat yang didukung angin naik yang menabrak lereng (dynamic lift) dan angin naik yang disebabkan thermal (thermal lift) (Panayiotis Kaniamos, 2012).

Obyek wisata adalah sebuah tempat berwisata/rekreasi yang biasanya merupakan gunung, danau, sungai, pantai, laut, dan lain-lain yang bisa dinikmati keindahan alamnya. Supaya suatu tempat dapat dikembangkan menjadi suatu obyek wisata, ada beberapa pedoman yang dapat dipakai sebagai acuan. Pengertian akan something to see yaitu segala sesuatu yang dapat dilihat, something to do yaitu segala sesuatu yang dapat dilakukan, dan something to buy yaitu segala sesuatu yang dapat dibeli seperti suvenir, makanan, dan minuman pada lokasi wisata tersebut (Oka A.Yoeti, 1997). Di dalam segala bidang atau suatu usaha, pengembangan merupakan suatu hal yang utama untuk menjadikan suatu bidang atau usaha tersebut mempunyai nilai lebih/manfaat, dan dapat memberikan keuntungan baik secara ekonomi maupun sosial termasuk bidang pariwisata.

\section{METODE}

Penelitian ini bersifat eksploratif dengan mengkaji potensi pengembangan olahraga dan wisata paralayang guna menjelaskan pengelolaan dan tata kelola paralayang oleh Pengurus Provinsi Paralayang Jawa Tengah dan keterlibatan stakeholder lainnya. Sampel penelitian ditentukan secara purposif pada Kabupaten Kudus. Variabel yang digunakan dalam penelitian ini adalah dimensi pengembangan olahraga paralayang dan indikator pada wisata paralayang oleh Pengurus Provinsi Paralayang Jawa Tengah. Data yang diperlukan dalam penelitian ini adalah data primer dan data sekunder. Data primer diperoleh langsung dari para pelaku pengembangan paralayang sebagai pakar/ahli dan layanan jasa, serta pihak-pihak pemangku kepentingan dari sisi penawaran. Data sekunder menggunakan dokumen berupa jurnal, file, buku, brosur, leaflet, peta wilayah, surat kabar, rekaman video, gambar, foto, hasil foto udara dari berbagai sumber. Teknik pengumpuan data yang dilakukan pada penelitian ini adalah desk research dan pengamatan lapangan dan wawancara. Data dan informasi yang diperoleh, dianalisis secara deskriptif kualitatif.

\section{HASIL DAN PEMBAHASAN}

Perkembangan paralayang mulai tahun 2010 sampai tahun terakhir ini cukup pesat, perkembangannya didukung dengan peningkatan kualitas sarana dan prasarana pendukung, terutama yang lokasi kegiatan penerbangan berada di lokasi wisata alam. Kajian potensi pengembangan olahraga dan wisata paralayang dengan wilayah sampel penelitian di Kabupaten Kudus (Ternadi) digunakan untuk melihat pengelolaan dan pengembangan olahraga wisata paralayang yang terintegrasi dengan obyek wisata alam. Hasil wawancara dan perolehan data lapangan disajikan berdasarkan dimensi dan indikator yang telah disusun pada Tabel 1 .

Kawasan wisata Ternadi di lereng Gunung Muria, Kabupaten Kudus merupakan tempat wisata alam yang lebih lama dikenal dengan wisata religinya. Kini kesan tersebut mulai pudar dengan adanya tontonan menarik dari olahraga sepeda down hill. Lokasi ini merupakan tempat terbang yang sangat memadai, karena didukung oleh angin, iklim, dan cuaca serta kontur tanah pegunungan yang sesuai dengan kebutuhan penerbangan parala- 
Tabel 1. Perbandingan data lapangan berdasarkan dimensi dan indikator

\begin{tabular}{|c|c|c|}
\hline Dimensi & Indikator & Ternadi \\
\hline \multirow[t]{6}{*}{ WILAYAH } & Sumberdaya bagi pariwisata & Ada \\
\hline & Sumber daya alam yang dapat dimanfaatkan & Banyak \\
\hline & Infrastruktur & Baik \\
\hline & Rencana Pengembangan & Ada \\
\hline & Kebijakan tata ruang & Ada \\
\hline & Koneksi antar destinasi wisata & Ada \\
\hline \multirow{5}{*}{$\begin{array}{l}\text { SOSIAL, EKO- } \\
\text { NOMI, BU- } \\
\text { DAYA, DAN } \\
\text { OLAHRAGA }\end{array}$} & Potensi untuk menggerakkan ekonomi lokal & Ada \\
\hline & Kesiapan budaya lokal dengan nilai-nilai pariwisata & Baik \\
\hline & Interaksi wisatawan dengan masyarakat lokal & Baik \\
\hline & Faktor penarik minat wisatawan untuk berkunjung & Ada \\
\hline & $\begin{array}{l}\text { Potensi pengembangan olahraga sesuai kondisi spesifik wisa- } \\
\text { ta }\end{array}$ & Tinggi \\
\hline \multirow[t]{4}{*}{ PRODUK } & Atraksi (daya tarik) & Ada \\
\hline & Amenitas (sarana prasarana) & Baik \\
\hline & Aksesibilitas (kemudahan akses) & Mudah \\
\hline & Aktivitas & Ada \\
\hline \multirow[t]{3}{*}{ PASAR } & Profil peminat paralayang & Muda \\
\hline & Intensitas pengembangan & Ada \\
\hline & Faktor pendorong motif & media sosial \\
\hline \multirow{3}{*}{$\begin{array}{l}\text { KELEM- } \\
\text { BAGAAN }\end{array}$} & Lembaga pengelola pengembangan paralayang & FASI \\
\hline & Peran Pengurus Provinsi Paralayang Jawa Tengah & aktif \\
\hline & $\begin{array}{l}\text { Dukungan pemerintah daerah terhadap pengembangan olah- } \\
\text { raga paralayang }\end{array}$ & Ada \\
\hline \multirow{3}{*}{$\begin{array}{l}\text { SUMBER DAYA } \\
\text { MANUSIA }\end{array}$} & Ketersediaan tokoh & Ada \\
\hline & $\begin{array}{l}\text { Ketersediaan, kualitas managerial, dan teknikal skill SDM } \\
\text { pengembangan paralayang }\end{array}$ & Minim \\
\hline & $\begin{array}{l}\text { Ketersediaan dan kualitas soft skill SDM pengembangan } \\
\text { paralayang }\end{array}$ & Minim \\
\hline
\end{tabular}

yang yang aman.

Infrastruktur pendukung pengembangan wisata diantaranya adalah akses jalan, lahan parkir, ketersediaan air bersih, toilet, dan jaringan komunikasi. Pada lokasi wisata Ternadi infrastruktur tersebut saat ini cukup lengkap. Akses jalan menuju lokasi take off paralayang masih berupa jalan berbatu yang rapi dan memungkinkan mobil bisa sampai diatas. Dengan pembangunan infrastruktur yang sejalan dengan kebijakan tata ruang, sangat mungkin bagi pengelola wisata untuk mengembangkan dan mengintegrasikan wisata - wisata terdekat untuk dipaketkan sebagi wisata yang lengkap. Dimana paket wisata ini akan dapat dinikmati oleh semua kalangan dan segala usia, dalam bentuk konsep "one stop recreation".

Selain keadaan lokasi wisata yang ber- sih, aman dan nyaman, keberadaan dan keterlibatan masyarakat menjadi faktor penarik minat bagi wisatawan untuk berkunjung (UU Kepariwisataan no.10, 2009). Akan jauh lebih baik ketika layanan atau wahananya pun turut berkembang, alam yang selama ini hanya dinikmati dengan dipandang dan diabadikan untuk selanjutnya terpajang dalam media sosial, dapat juga dikembangkan untuk wahana baru, seperti paralayang, outbound circuit, flying fox, atau wahana menantang lainnya, seperti hiking track. Sebagai olahraga khusus, paralayang dilihatnya saja sudah sangat menarik, apalagi mencoba merasakannya dengan terbang tandem. Ketika wahana - wahana baru ini berkembang disebuah lokasi wisata, bukan tidak mungkin pemberdayaan masyarakat lokal akan meningkat pesat, seiring dengan ke- 
butuhan tenaga bantuan pendukung, contohnya pada kegiatan penerbangan paralayang, akan dibutuhkan tenaga bantuan pendukung, seperti pemandu wisata paralayang, ojek menuju take off, dan paraboy,.

Ternadi merupakan tempat wisata yang sudah dikenal dan banyak dikunjungi wisatawan, sudah sangat siap dalam menerima kedatangan pengunjung hingga memanjakannya dengan keindahan alam dan kesejukan udaranya. Pengunjung tempat wisata saat ini, tidak hanya mencari tempat yang murah, pengunjung cenderung mencari yang mudah untuk mencapainya, memiliki keunikan atau ciri khas tertentu, serta menarik. Informasi mengenai hal tersebut banyak yang wisatawan dapat berdasarkan berita atau informasi lain dari berbagai media, untuk saat ini yang menarik adalah berita dari media sosial, karena peliputnya adalah jejaring pertemanan yang bisa dijadikan referensi dengan rekomendasinya. Melalui media sosial yang beritanya cukup up to date, wisatawan dapat mengerti banyak hal sebelum mengunjunginya (Evi Rusvitasari dan Agus Solikhin, 2018). Maraknya pemanfaatan media sosial dengan multimedianya, sangat membantu promosi dari sebuah tempat wisata. Kegiatan terbang paralayang yang dilakukan di Ternadi telah diketahui banyak masyarakat. Banyak pula pertanyaan yang diajukan baik kepada penggiat paralayang maupun kepada masyarakat sekitar, mulai dari ketertarikannya untuk bergabung dan berminat belajar terbang paralayang atau hanya ingin merasakan terbang dengan dipandu oleh tandem master. Kalangan muda Kudus dan sekitarnya merupakan kelompok terbanyak yang menanyakan dan berminat terhadap kegiatan penerbangan paralayang, rata - rata alasan pengunjung yang berminat terhadap paralayang adalah karena menyukai keseruannya, memacu adrenalin, atau mencoba hal baru, namun diantara banyak hal tersebut, satu alasan yang cukup menarik adalah pengunjung bisa publikasi di media social yang ada.

Sebagai olahraga yang relatif baru, perkembangan paralayang masih sangat membutuhkan dukungan dari banyak pihak. Keterlibatan pemerintah dalam mengembangkan paralayang telah membuat paralayang berkembang di daerahnya masing - masing. Dari 35 wilayah kabupaten maupun kota di Jawa Tengah, hingga saat ini sudah ada 21 daerah yang dikembangkan oleh Pengurus Provinsi Paralayang Jawa Tengah dan sudah aktif kepengurusannya serta berada dibawah binaan
KONI masing - masing daerahnya. Penggiat paralayang Ternadi di Kabupaten Kudus tergabung dalam Komunitas Paralayang Kudus (KOMPAS), kegiatan anggota didukung oleh FASI dan KONI Kabupaten Kudus. Perkembangan komunitas ini di Kudus dirasakan sangat lambat, tidak ada tambahan anggota baru yang berlanjut hingga mendapatkan Lisence (Joe Schofield, 1970), adapun alasan anggota adalah keterbatasan biaya.

Unsur yang sangat penting sebagai pelaku atau operator usaha adalah kualitas sumber daya manusia yang utama. Pilot paralayang harus memiliki kualifikasi tertentu yang ditandai dengan memiliki lisensi penerbangan paralayang (APPI, 1996). Mendapatkan lisensi ini selain banyak materi yang harus dipelajari dan diujikan, juga membutuhkan biaya yang cukup mahal walaupun bisa disikapi dengan bijak, hal inilah yang membuat citra paralayang dianggap sebagai olahraga mahal. Perjalanan proses kepemanduan wisata paralayang merupakan proses yang lebih panjang, ketika sebuah daerah ingin mengembangkan wisata tandem paralayang, maka harus tersedia pilot yang berkualifikasi tandem.

\section{SIMPULAN}

Kerjasama dengan pihak terkait adalah salah satu jalan untuk keberlangsungan kegiatan tersebut. Butuh keterlibatan dari banyak pihak terkait untuk menyelesaikan masalah tersebut. Fitur wisata tambahan ini menjadi pelengkap, sehingga bisa tercapai upaya menjadi "one stop recreation".

\section{DAFTAR PUSTAKA}

Anggaran Dasar dan Anggaran Rumah Tangga (AD/ART) Federasi Aero Sport Indonesia (FASI). 2010.

APPI Internasional, 1996. APPI Flight Logbook for Solo Pilot. Switzerland.

Evi Rusvitasari dan Agus Solikhin, 2018. Strategi Pengembangan Wisata Alam Dalam Meningkatkan Kunjungan Wisatawan di Obyek Wisata Umbul Sidomukti Bandungan Semarang, diakses pada 29/01/2018, jam 13:35.

Joe Schofield, 1970. Elementary Pilot Training Guide. BHPA. Inggris.

Oka A. Yoeti, 1997. Perencanaan dan Pengembangan Pariwisata. Jakarta: Pradnya Paramita

Panayiotis Kaniamos. 2012. Pocket Aviation ${ }^{\mathrm{TM}}$ - A Guide to Paragliding. ISBN 960-90460-1-0. Greece.

Undang-Undang Sistem Keolahragaan Nasional No.3 Tahun 2005.

Undang-Undang No 10. 2009: pasal 1. Tentang Kepariwisataan. Bandung: Penerbit Citra Umbara 